\title{
Natural occurrence of papaya ringspot virus in Clitoria ternatea in India
}

\author{
Siriya Sultana ${ }^{1} \cdot$ Buddhadeb Roy $^{1} \cdot$ Ang Rinzing Sherpa $^{1}$ (t) \\ Received: 28 May 2018 / Accepted: 14 July 2018 / Published online: 20 July 2018 \\ (C) Società Italiana di Patologia Vegetale (S.I.Pa.V.) 2018
}

Symptomatic Clitoria ternatea plants exhibiting typical symptoms of potyvirus infection such as leaf curling and deformations were found in West Bengal, India in 2016-2017. Rod shaped flexuous particles of $\sim 700 \times 13 \mathrm{~nm}$ were observed in some symptomatic plants by transmission electron microscopy. To confirm the presence of a potyvirus, symptomatic plants were analyzed by antigen-coated plate-ELISA using potyvirus specific antibodies (Agdia, USA). Nine out of 14 samples tested were positive in ACP-ELISA. In addition, RTPCR products $327 \mathrm{bp}$ in size were obtained from total RNA isolated from leaves of symptomatic plants with universal potyvirus primers (Marie-Jeanne et al. 2000). To identify a potyvirus species, primers were designed in conserved regions of the nuclear inclusion protein $(\mathrm{NIb})$ and coat protein genes of papaya ringspot virus (PRSV) (PRSV-CP-F: 5' TTTGAGCGAGARAGRGGAGA 3' and PRSV-CP-R: 5' CCAGGAGAGAGTGCATGTCT 3') to amplify a $975 \mathrm{bp}$ fragment from total RNA of symptomatic $C$. ternatea samples by RT-PCR. The PCR products were bi-directionally sequenced and BLASTn analysis showed $89-91 \%$ nucleotide sequence identity of the PRSV isolates from C. ternatea in India (DDBJ accession number LC331253) with previously reported $\mathrm{P}$ and $\mathrm{W}$ type $\mathrm{PRSV}$ isolates from China
(KY933061), East Timor (KX655865), Taiwan (JX448373) and India (KJ755852). To the best of our knowledge, this is the first report of $C$. ternatea as a natural host and potential reservoir host of PRSV.

Acknowledgements We acknowledge Director, National Institute of Cholera and Enteric Diseases for providing the TEM facility for this investigation. Authors would like to thank Department of Science and Technology, New Delhi for SERB Project Grant No. SR/FT/LS-165/2012 and financial assistant from University Grant Commission (UGC), New Delhi to Miss Siriya Sultana, Senior Research Fellow (Maulana Azad National Fellowship) in the form of fellowship is greatly acknowledged.

\section{Compliance with ethical standards}

Conflict of interest The authors declare that we have no conflict of interest.

\section{Reference}

Marie-Jeanne V, Ioos R, Peyre J, Alliot B, Signoret P (2000) Differentiation of Poaceae Potyviruses by reverse transcriptionpolymerase chain reaction and restriction analysis. J Phytopathol 148:141-151
Ang Rinzing Sherpa

ang2001@gmail.com

1 West Bengal State University, Malikapur, Berunanpukuria, 24 North Parganas, Barasat, Kolkata, W.B. 700126, India 